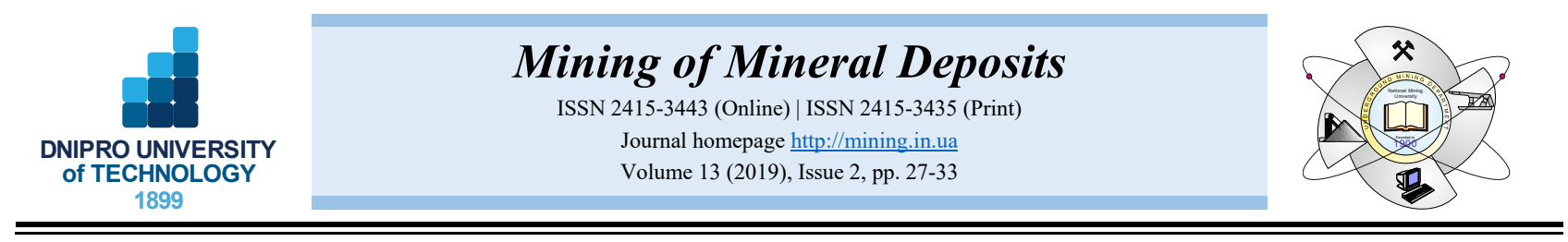

UDC 622.831.3:622.288

https://doi.org/10.33271/mining13.02.027

\title{
THE INFLUENCE OF RIGIDITY OF THE COLLAPSED ROOF ROCKS IN THE MINED-OUT SPACE ON THE STATE OF THE PREPARATORY MINE WORKINGS
}

\author{
V. Bondarenko ${ }^{1 *}$, H. Symanovych ${ }^{1}$, J. Kicki ${ }^{2}$, M. Barabash ${ }^{3}$, I. Salieiev ${ }^{4}$ \\ ${ }^{1}$ Dnipro University of Technology, Dnipro, Ukraine \\ ${ }^{2}$ Mineral and Energy Economy Research Institute of the Polish Academy of Sciences, Krakow, Poland \\ ${ }^{3}$ LLC "DTEK Energy", Kyiv, Ukraine \\ ${ }^{4}$ PJSC "Donetsksteel" - Iron and Steel Works", Kyiv, Ukraine \\ *Corresponding author: e-mail v_domna@yahoo.com, tel. +380562471472,fax: +380563742184
}

\begin{abstract}
Purpose. The substantiation of accounting the deformation-strength characteristics of the collapsed rocks and the rocks consolidating near the reusable preparatory mine working of the mined-out space to optimize the loading parameters of its fastening and security systems. Improving the research adequacy and recommendations reliability.
\end{abstract}

Methods. By means of computational experiments based on the finite-element method, the influence has been studied of rigidity of the collapsed rocks and consolidating rocks in the mined-out space on the level of intensity of the load-bearing elements of the fastening and security systems of mine working. The analysis has been performed of the stress-strain state of the geomechanical system load-bearing elements, as well as comparative mine research.

Findings. The research results and analysis are represented of the stress-strain state of the fastening and security systems elements in the preparatory mine workings with different degree of rigidity of the collapsed and consolidated rocks of the mined-out space. The patterns of the rigidity influence of the collapsed roof rocks on the stable state of preparatory mine workings have been assessed.

Originality. A different-valued relation has been established between the deformation-strength characteristics of the collapsed rocks in the mined-out space and the elements of fastening and security systems of mine working, which should be considered when optimizing the modes of their operation. It has been revealed that the increased loading on the combined roof-bolting system elements protects the frame support from the increased rock pressure, which contributes to reducing the section losses of mine working.

Practical implications. The research performed is the basis for the parameters optimization when maintaining the preparatory mine workings for their repeated use and also for the rational parameters search of the combined roof-bolting system in order to develop a method for choosing its parameters depending on mining and geological conditions.

Keywords: collapsed rocks, preparatory mine working, stress-strain state, deformation-strength characteristics, support, roof rocks rigidity

\section{INTRODUCTION}

When considering the trends of the main geomechanics factors influence on the state of fastening and security systems of the preparatory mine workings in the zone of the stope works influence (Bondarenko, Kovalevska, Symanovych, Barabash, \& Snihur, 2018; Kovalevska, Barabash, Husiev, \& Snihur, 2018), a certain impact have been constantly observed on each other all of the load-bearing elements constituting the diagram for maintaining the mine working. And the degree of this impact largely depended on how different their operation modes are in the process of resistance to the rock pressure manifestations (Majcherczyk, Niedbalski, \& Malkowski, 2007). For example, if rigid and pliable elements interact with each other, then usually in the area of their contact in the pliable element, the significant perturbations of stresses components occur, which often reach the destructive values (Kulczycka, Hałasik, Nowaczek, Whirt, \& Szkop, 2017). Therefore, it is a very important issue of matching between the deformation-strength characteristics of the elements included into the fastening system of mine working, against their total adaptation to the nature of rock pressure, conditioned by the action of geome-

(C) 2019. V. Bondarenko, H. Symanovych, J. Kicki, M. Barabash, I. Salieiev. Published by the Dnipro University of Technology on behalf of Mining of Mineral Deposits. This is an Open Access article distributed under the terms of the Creative Commons Attribution License (http://creativecommons.org/licenses/by/4.0/),

which permits unrestricted reuse, distribution, and reproduction in any medium, provided the original work is properly cited. 
chanics factors combination (Kovalevska, Barabash, Husiev, \& Snihur, 2018; Bondarenko, Kovalevska, Symanovych, Barabash, \& Snihur, 2018), including the rigidity of the collapsed rocks and the rocks of immediate and main roof being consolidated in the mined-out space of the longwall face (Kovalevska, Vivcharenko, \& Snigur, 2013; Symanovych, Demydov, \& Chervatuk, 2013).

Under the concept of rigidity of the longwall face collapsed rocks we understand the dependence of their repulse reaction to the lowering overlying layers of the coal-overlaying formation on the shrinkage value of the collapsed rocks in the mined-out space. As such, a deformation-strength characteristic of rocks in the zone of uncontrolled collapse of the mined-out space near the preparatory mine workings has been considered, which integrally describes their behaviour in the process of displacement of the coal-bearing massif behind the stope face. The consideration of this geomechanics object is conditioned by a number of factors that, in our opinion, should be taken into account when substantiating and choosing the rational operation modes of the fastening and security systems of preparatory mine workings (Bondarenko, Kovalevs'ka, \& Fomychov, 2012; Kovalevska, Symanovych, \& Fomychov, 2013; Lozynskyi, Saik, Petlovanyi, Sai, \& Malanchuk, 2018; Rak, Cieślik, Stasica, \& Dvořák, 2018).

The main factor is that the more rigid the deformation-strength characteristic of the collapsed rocks (the increased repulse reaction with reduced shrinkage value), the less the lowering of the main roof rocks, and the more restricted area of their weakening, which leads to the formation of a decreased load on the fastening system and reduces the section loss of the drift. The subordinated factor is closely related to the main one: the high repulse reaction at a decreased vertical displacement creates an effective bearing for the overlying layers of the main roof from the side of mined-out space; if the adjacent rock layers are still divided into blocks under the influence of vertical rock pressure, then as the height of the rock layer location increases, its stability will also increase due to the presence of two bearings with a high repulse reaction and decrease in the span length of the rock beam owing to the expansion in the area of bearings influence throughout the height of the roof (Kendzera \& Semenova, 2017; Lazarević, Uroš, \& Čengija, 2017; Haiko, Matviichuk, Biletskyi, \& Saluga, 2018; Khalymendyk \& Baryshnikov, 2018).

Thus, with a sufficiently rigid deformation-strength characteristic of the collapsed rocks, the stabilization of the displacement process of the coal-overlaying formation occurs at a shorter distance behind the stope face at a more restricted height of extension of the weakening area into the roof; as a result - the decrease in the load on the fastening system and the section loss of the drift.

The degree of the collapsed rocks rigidity in the minedout space is determined by the composing lithotypes, their structure and mechanical properties (Hassani, Farokhnia, Sarkheil, \& Dizaji, 2010; Naduty, Malanchuk, Malanchuk, \& Korniyenko, 2015; Yu, Niu, Kong, Hao, \& Cao, 2015). From the classical provisions of mine rock mechanics, it is known that the degree of fragmentation increases with an increase in the strength and thickness of collapsing rock layers (Bulychev, 1982), and also depends on the type of lithological variety: for example, the fragmentation degree of sandstone is significantly higher than that of siltstone, and the fragmentation degree of siltstone is higher than that of argillite. The same provisions of mine rock mechanics indicate the pattern of inversely proportional relation between the fragmentation degree and the thickness of the zone of uncontrolled collapse, and the lower its height, the more rigid deformation-strength characteristic: with a reduced lowering of the main roof rocks, the value of reaction is formed, which is sufficient to stabilize the displacement process of the coal-overlaying formation.

These considerations have substantiated the need to study the degree of influence of the collapsed rocks rigidity in the mined-out space on the state of the fastening and security systems elements of the reused drift in terms of assessing their operation modes rationality. The modelling of different rigidity of the collapsed rocks has been performed by the finite element method (FEM) (Bock \& Prusek, 2015; Witek \& Prusek, 2016; Bondarenko et al., 2017) by way of changing their deformation modulus, which is an averaged characteristic of relation between their reaction and the shrinkage value.

The analysis of the state of the fastening and security system elements has been performed by two stresses components: vertical $\sigma_{y}$ and stresses intensity $\sigma$.

\section{RESEARCH AND ANALYSIS OF VERTICAL STRESSES COMPONENTS}

The two curves of the vertical stresses $\sigma_{y}$ distribution in the elements of the fastening and security systems of the drift, which correspond to the variants of increased and decreased collapsed rocks rigidity of the mined-out space are shown in Figure 1.

With an increased rigidity of the collapsed rocks (Fig. 1a), the distribution of $\sigma_{y}$ in the fastening system is characterized by the following peculiarities:

- the most part of the cap board length on its sides is in a very unloaded state with a fluctuation from $5 \mathrm{MPa}$ of tension to $20 \mathrm{MPa}$ of compression;

- in the central part of the arch with a length of about $1.2 \mathrm{~m}$, the tensile stresses $\sigma_{y}$ act up to $30 \mathrm{MPa}$, which amount only $11 \%$ of the limit of strength of SCP steel;

- in the contact with the central prop stay of the strengthening support, the moderate concentrations of compressive stresses $\sigma_{y}$ up to $40-55 \%$ of the estimated yield limit value occur, which is also confirmed by mine observations (Fig. 2).

The described distribution of $\sigma_{y}$ in the frame cap board is subjected to a series of changes for a variant with decreased collapsed rocks rigidity (Fig. 1b):

- in the area of the yielding joists location, the curve $\sigma_{y}$ is not almost changed if compared with the previous variant, but as it moves to the central part of the arch, the compressive stresses $\sigma_{y}$ increase by $2-5$ times, reaching $70-100 \mathrm{MPa}$, and this, nevertheless, does not constitute a danger to the cap board stability;

- there is also an increase in tensile stresses $\sigma_{y}$ in the central part of the arch up to the values of $50-80 \mathrm{MPa}$, which amount to $15-30 \%$ of the yield limit of the steel;

- at the same time, the concentration of compressive stresses $\sigma_{y}$ in the contact with the central prop stay of the strengthening support is reduced very intensively. 
(a)

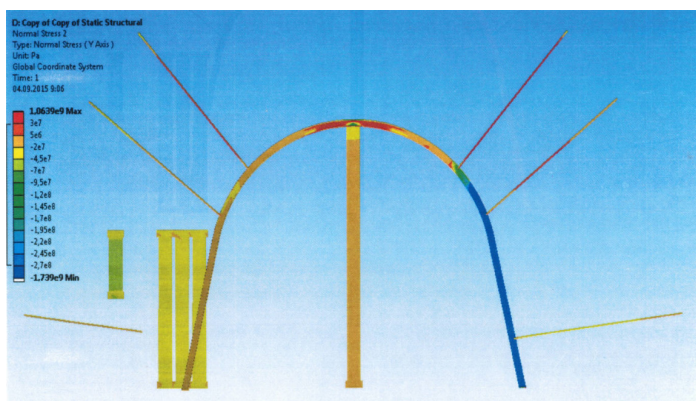

(b)

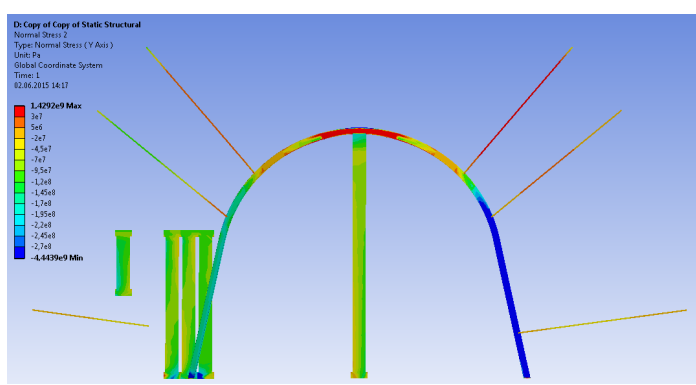

Figure 1. The fragment of the vertical stresses $\sigma_{y}$ distribution in the fastening and security systems of the preparatory mine working, depending on the deformationstrength rocks characteristics of the zone of uncontrolled collapse in the mined-out space: increased (a) and decreased (b) rigidity of the collapsed rocks

(a)

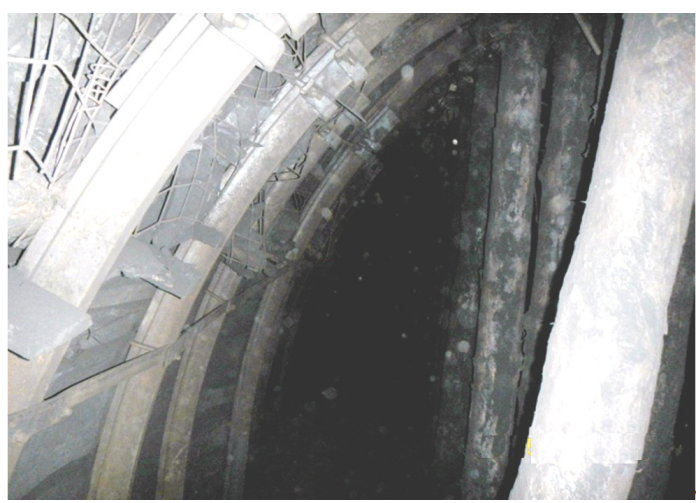

(b)

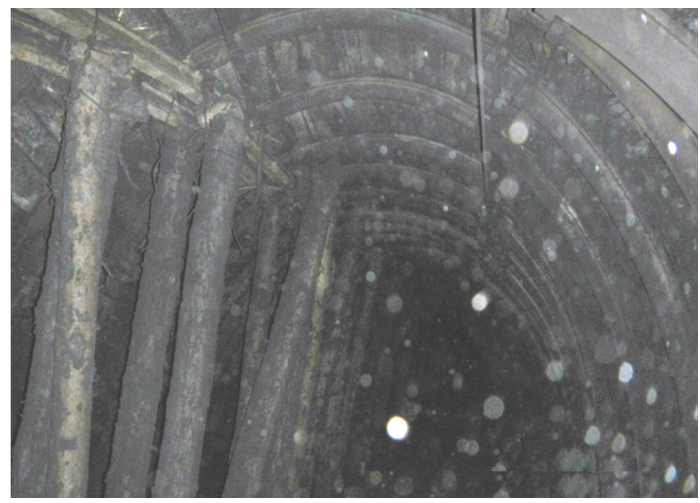

Figure 2. The fragments of the state of a working flank (a) and non-mining flank (b) of the reusable zonal drift with increased collapsed rocks rigidity in the minedout space
The comparison of the obtained results indicates a certain increase in the loading of the frame cap board under the conditions of decreased rigidity of the collapsed rocks, which, however, does not constitute a danger to its stability. Obviously, an increase in the load on the cap board is conditioned by the increased shrinkage of the collapsed rocks, but the yielding mode of the cap board operation still copes with the function of its protection from the excessive rock pressure.

On the other hand, the wooden prop stay of the strengthening support restricts the yielding mode of the cap board operation, and here the following situation arises relative to peculiarities of its deformation. The cap board has three bearings: two pliable bearings on its sides (near the frame joists) and one rigid bearing in the contact with the central prop stay of the strengthening support. Under the influence of the vertical load, the halfbranches of the cap board tend to bend, since their bearings along the edges work in a yielding mode and allow for the possibility of significant movements. The place of the cap board bending determines the location of the rigid central bearing. In addition, an enough intensive distribution of tensile stresses $\sigma_{y}$ occur in the resingrouted roof bolts (which are close to the vertical axis of mine working), therefore, a significant vertical load on the frame is formed (from the stratified roof rocks), which contributes to flexure strains of the half- branch of the cap board relative to the rigid central bearing. Then it is quite explainable the extended area of tensile stresses $\sigma_{y}$ in the central part of the cap board: when bending, the cap board tends to elongate and its tension happens.

Here we are again faced with a mutual influence on each other of operation modes of different elements of the fastening system of the drift. Unlike the yielding operation mode of the frame cap board, the rigid deformation-strength characteristic of a wooden prop stay of the strengthening support predetermines a significant increase in its loading when worsening the conditions for maintaining a drift according to the factor of the increased shrinkage value of the collapsed rocks. Thus, with their increased rigidity, the overwhelming part of the wooden prop stay length is loaded with compressive stresses $\sigma_{y} \leq 20 \mathrm{MPa}$, which does not exceed $50 \%$ of the value of calculated resistance of pine to compression. In the area with height up to $200 \mathrm{~mm}$, near the contact with the frame cap board, the vertical stresses reach $100 \%$ of the calculated resistance of pine to compression and here only a local wood contortion is possible (Fig. 2).

At the same time, at a decreased rigidity of the collapsed rocks, a more intensive lowering of the coaloverlaying formation causes a sharp increase in the load on the wooden prop stay of the strengthening support, which has rigid deformation-strength characteristics:

- the compressive stresses $\sigma_{y}$ reach the values of $70-120 \mathrm{MPa}$ and by $1.75-3.0$ times exceed the calculated resistance of pine to compression;

- a differential of compressive stresses $\sigma_{y}$ occurs in the cross section of the prop stay, which indicates the action of the bending moment, causing the bend of the prop stay in the direction of mined-out space (Fig. 3).

This combination of predominantly superlimiting state of wood with the impact of a bending moment makes it possible to predict the stability loss of the central prop 
stay of the strengthening support, which excludes it from the work to resist to the rock pressure. Thus, the degree of the collapsed rocks shrinkage in the mined-out space influences quite significantly on the state of a rigid wooden prop stay of the strengthening support.

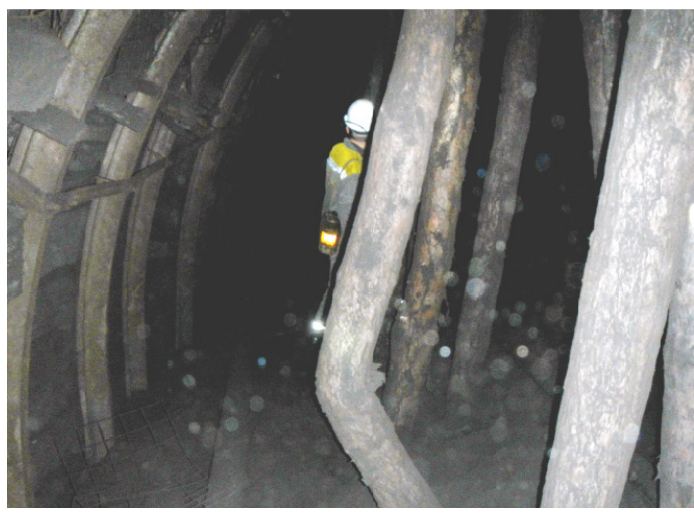

Figure 3. The fragment of a state of the zonal mine working support with a decreased rigidity of the collapsed rocks in the mined-out space

The same significant influence of the collapsed rocks rigidity is also observed on the state of the rows of side wooden prop stays of the strengthening support. With an increased collapsed rocks rigidity, their significant resistance to rock pressure contributes to a quite stable state (mainly to prelimiting state) of the wooden prop stays according to the factor of the component $\sigma_{y}$ action. When decreasing the collapsed rocks rigidity, their resistance to vertical rock pressure decreases (at the identical displacements). This value of resistance decrease should be redistributed to other elements of maintaining, including the side prop stays of the strengthening support. As a result, the value $\sigma_{y}$ increased up to $70-120 \mathrm{MPa}$, which exceeds the calculated resistance of pine to compression by $1.75-3.0$ times. In addition, a significant bending moment appears (in the second and third rows of prop stays - in two areas throughout their height), which contributes to stability loss of the prop stays working in a rigid mode of resistance to rock pressure.

In the prop stays of the frame support there is an ambiguous influence of the collapsed rocks rigidity. Thus, the prop stay from the side of mined-out space at an decreased shrinkage of the collapsed rocks (Fig. 1a) is in a quite unloaded state; the overwhelming part of its length is subjected to $\sigma_{y} \leq 20 \mathrm{MPa}$, and only in a limited area of a length of $0.3-0.4 \mathrm{~m}$ the compressive stresses $\sigma_{y}=25-45 \mathrm{MPa}$ act, which does not exceed $17 \%$ of the yield limit of SCP steel. Such situation is caused by the action of three components, which take up the main volume of the vertical rock pressure: the collapsed rocks with increased rigidity, central wooden prop stays of the strengthening support and three rows of side wooden prop stays of the strengthening support.

The decrease in the resistance of the collapsed rocks while reducing their rigidity (Fig. 1b) causes a redistribution of load (from the side of the roof rocks) to other elements of the diagram for maintaining the drift, including the frame prop stay from the side of mined-out space. Here, except for the local area near the yielding joist, the compressive stresses $\sigma_{y}$ are changed in the range of
$90-150 \mathrm{MPa}$, which on average is half as much as the yield limit of SCP steel and characterizes the state of the prop stay as stable, despite its rigid mode of operation. This is mainly conditioned by the resistance of the central and side prop stays of the strengthening support.

Thus, on the one hand, the influence of the rigidity of rocks collapsed in the mined-out space is very significant in terms of $\sigma_{y}$ growth (at an average by $4-6$ times), but, on the other hand, the prop stay does not lose stability and is in a state far from the limiting one.

A different situation is observed for the frame prop stay from the side of massif; it is subjected to considerable load even in favourable conditions of increased rigidity of the collapsed rocks: the vertical stresses $\sigma_{y}$ are either close or correspond to the value of yield limit of SCP steel, but in cross section of the prop stay there are no signs of any significant bending moment. The same pattern is observed with decreased rigidity of the collapsed rocks with a slight increase of $\sigma_{y}$ up to $8-11 \%$.

The increased load on the frame prop stay from the side of virgin massif is a very common phenomenon, and the weak influence of the collapsed rocks rigidity can be explained by their remoteness from the prop stay, where the main loading factor is the weight of unstable roof rocks from the side of massif.

The significant difference in the degree of loading the two prop stays of the frame, working in approximately the same rigid mode, is conditioned by the influence of the deformation-strength characteristics not only of the collapsed rocks, but also of other fastening elements (central and side prop stays of the strengthening support).

\section{RESEARCH AND ANALYSIS OF STRESSES INTENSITY}

The outcome of a significant influence of the rocks rigidity in the zone of uncontrolled collapse on the state and operation mode of the fastening elements in the preparatory mine workings has been confirmed when analysing the curves of the stresses intensity $\sigma$ distribution shown in Figure 4.

The cap board of the frame (under the conditions of increased collapsed rocks rigidity) is in a relatively unloaded state (Fig. 4a):

- in its peripheral areas near the yielding joists, the minimal $\sigma_{y} \leq 20 \mathrm{MPa}$ act;

- when moving closer to the central part of the arch, the stresses intensity increases up to $130-180 \mathrm{MPa}$, which is conditioned by the influence of the central prop stay of the strengthening support;

- at a distance of $250-380 \mathrm{~mm}$ from the vertical axis of mine working, two concentration areas of $\sigma_{y}=210-260 \mathrm{MPa}$ are located symmetrically throughout the entire height of the SCP section, where, primarily, the limiting state is likely with the slightest worsening of the mining and geological conditions;

- directly in the entire contact area of the cap board and the central prop stay of the strengthening support, an area of the SCP plastic state is formed to a depth of up to $40 \mathrm{~mm}$.

The general state of the frame cap board can be assessed as stable, but there are preconditions for the plastic flow of SCP in the area of contact with a rigid wooden prop stay of the strengthening support. 
(a)

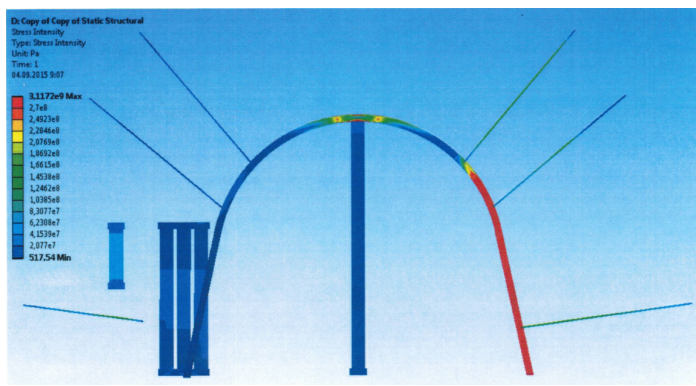

(b)

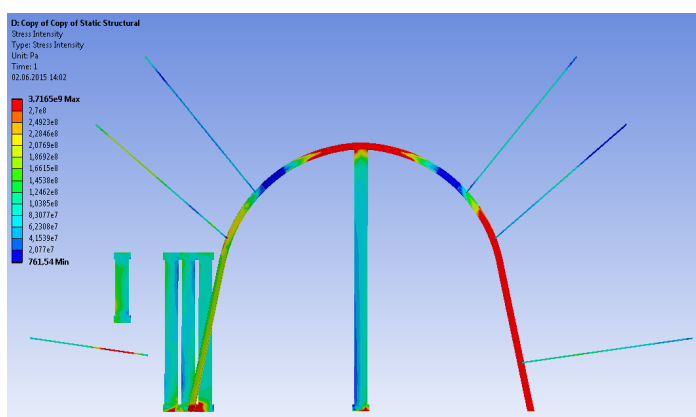

Figure 4. The fragment of the stresses intensity $\sigma$ distribution in the fastening and security systems of the preparatory mine working depending on the deformationstrength characteristics of rocks in the zone of uncontrolled collapse in the mined-out space: increased (a) and decreased (b) rigidity of the collapsed rocks

The predicted plastic state of the central part of the cap board (at length up to $1.3 \mathrm{~m}$ ) occurs in the variant with decreased rigidity of the collapsed rocks (Fig. 4b). The main reason is the rigid operation mode of the wooden prop stay of the strengthening support, which induces the plastic bending of the cap board half-branches.

The central prop stay itself of the strengthening support is also subjected to a significant influence of the degree of collapsed rocks shrinkage in the mined-out space. With their increased rigidity, there is a uniform field (absence of a bending moment) of stresses intensity with value not more than $20 \mathrm{MPa}$, which is half the value of the calculated resistance of pine to compression. From this it follows that despite the rigid mode of a wooden prop stay operation, the close location of another rigid element (collapsed rocks) preserves the quite stable state of this prop stay.

On the contrary, when decreasing the collapsed rocks rigidity, a part of the load is redistributed to the central wooden prop stay of the strengthening support. As a result, not only the stresses intensity increases in it, but also a bending moment occurs; the combination of the limiting or superlimiting state of wood of the prop stay with the bending moment, definitely leads to its stability loss.

A similar situation is observed with the rows of side wooden prop stays of the strengthening support. Their extremely stable state with an increased collapsed rocks rigidity is replaced by an unstable one (the stresses intensity exceeds by $1.5-2.5$ times the calculated resistance of pine to compression) in the variant with the decreased collapsed rocks rigidity. Obviously, the observed trends reflect a single mechanism for the load redistribution on the rigidity elements at least of one of them.
The prop stays of the frame support according to the factor of stresses intensity $\sigma$ distribution react differently to changes in the collapsed rocks rigidity. From the side of mined-out space, with an increased collapsed rocks rigidity, the prop stay of the frame is extremely unloaded: a value of $\sigma_{y} \leq 20 \mathrm{MPa}$, which does not exceed $7.4 \%$ of the estimated yield limit of SCP steel; the bending moment is almost absent. The main reason for this state of the frame prop stay is that the most of the load from the lowering rocks of the coal-overlaying formation is taken up by the zone of uncontrolled collapse, which is a very rigid and extensive in area, while maintaining the thrust forces between the rock blocks above the mine working and above the adjacent part of mined-out space of the longwall face. These thrust forces of blocks make it possible to create a resistive action to the vertical component of the rock pressure and distribute it over a larger area of the mined-out space, which reduces significantly the lateral shifts of the collapsed rocks in the direction of the security and fastening systems of the maintained mine working. When decreasing the rigidity of this zone rocks, a part of the load is redistributed to the frame prop stay:

- in its curvilinear part, the stresses intensity reaches $200-260 \mathrm{MPa}$, that is, the state of the prop stay is approaching the limiting one $(75-95 \%$ of the yield limit of SCP steel);

- a significant bending moment acts with the direction of the curvilinear part bend towards the mined-out space;

- along the main length of the rectilinear part of the prop stay, a moderate bending moment acts with the bend direction into the cavity of mine working.

The frame prop stay from the side of massif is very poorly influenced by the collapsed rocks rigidity; it is in the limiting and superlimiting states (without significant bending moments), and the decrease in the collapsed rocks rigidity increases the stresses intensity by no more than $5-8 \%$.

\section{CONCLUSIONS}

The influence of the collapsed rocks rigidity of the mined-out space on the loading of the fastening and security systems of the preparatory mine working is determined by the thrust forces between the rock blocks above the mine working and above the adjacent part of mined-out space of the longwall face. These thrust forces of blocks resist to the vertical component of the rock pressure and contribute to its distribution over a larger area of the mined-out space, which reduces significantly the lateral shifts of the collapsed rocks in the direction of the security and fastening systems of the maintained mine working.

A different-valued relation is evident of the deformation-strength characteristics of the collapsed rocks in the mined-out space, fastening and security elements of the extraction mine working, which should be considered in their operation modes optimization.

There is a mutual influence on each other of the deformation-strength characteristics of different elements included into the diagram for maintaining the extraction mine working after passing the stope face; this fact is also required to take into account when substantiating and choosing the rational operation modes of the fastening systems as a whole. 


\section{ACKNOWLEDGEMENTS}

The authors express their gratitude to the management of DTEK Coal Unit for their assistance in organizing the experimental research.

\section{REFERENCES}

Bock, S., \& Prusek, S. (2015). Numerical study of pressure on dams in a backfilled mining shaft based on PFC3D code. Computers and Geotechnics, (66), 230-244. https://doi.org/10.1016/j.compgeo.2015.02.005

Bondarenko, V., Kovalevs'ka, I., \& Fomychov, V. (2012). Features of carrying out experiment using finite-element method at multivariate calculation of "mine massif - combined support" system. Geomechanical Processes During Underground Mining - Proceedings of the School of Underground Mining, 7-13. https://doi.org/10.1201/b13157-3

Bondarenko, V., Kovalevskaya, I., Simanovich, G., Barabash, M., Snigur, V., \& Gusev, A. (2017). Kombinirovannye ankernye sistemy dlya povtornogo ispol'zovaniya gornykh vyrabotok. Dnipro: LizunovPres.

Bondarenko, V., Kovalevska, I., Symanovych, H., Barabash, M., \& Snihur, V. (2018). Assessment of parting rock weak zones under the joint and downward mining of coal seams. E3S Web of Conferences, (66), 03001. https://doi.org/10.1051/e3sconf/20186603001

Bulychev, N.S. (1982). Mekhanika podzemnykh sooruzheniy. Moskva: Nedra.

Haiko, H., Matviichuk, I., Biletskyi, V., \& Saluga, P. (2018). Forecast assessment methods of geological environment promotion for the construction of urbanistics subjects. Visnyk of V.N. Karazin Kharkiv National University - Series Geology Geography Ecology, (48), 39-51. https://doi.org/10.26565/2410-7360-2018-48-03

Hassani, H., Farokhnia, M., Sarkheil, H., \& Dizaji, M. (2010). Numerical stability analysis of tectonically disturbed and lithologically varied rock masses of collapsed pressure shaft slope in Siah Bishe Dam, North Iran. Rock Stress and Earthquakes, 539-543. https://doi.org/10.1201/b10555-93

Kendzera, A., \& Semenova, Yu. (2017). Deformation characteristics of computational models of soil strata. Visnyk of Taras Shevchenko National University of Kyiv. Geology, 3(78), 17-29. https://doi.org/10.17721/1728-2713.78.03

Khalymendyk, I., \& Baryshnikov, A. (2018). The mechanism of roadway deformation in conditions of laminated rocks. Journal of Sustainable Mining, 17(2), 41-47. https://doi.org/10.1016/j.jsm.2018.03.004

Kovalevska, I., Symanovych, G., \& Fomychov, V. (2013). Research of stress-strain state of cracked coal-containing massif near-theworking area using finite elements technique. Annual ScientificTechnical Collection - Mining of Mineral Deposits, 159-163. https://doi.org/10.1201/b16354-28
Kovalevska, I., Vivcharenko, O., \& Snigur, V. (2013). Specifics of percarbonic rock mass displacement in longwalls end areas and extraction workings. Annual Scientific-Technical Collection - Mining of Mineral Deposits 2013, 29-33. https://doi.org/10.1201/b16354-7

Kovalevska, I., Barabash, M., Husiev, O., \& Snihur, V. (2018). Interaction of deformation-strength characteristics of the support load-bearing elements in the preparatory workings. E3S Web of Conferences, (60), 00002. https://doi.org/10.1051/e3sconf/20186000002

Kulczycka, J., Hałasik, K., Nowaczek, A., Whirt, H., \& Szkop, R. (2017). The analysis of factors, barriers and conditions that affect the attractiveness of mining investment in Poland own research. Mining Science, (24), 209-226. https://doi.org/10.5277/msc172414

Lazarević, A.J., Uroš, M., \& Čengija, A. (2017). Fundamental models of structural stability. Rudarsko Geolosko Naftni Zbornik, 32(2), 37-46. https://doi.org/10.17794/rgn.2017.2.5

Lozynskyi, V., Saik, P., Petlovanyi, M., Sai, K., \& Malanchuk, Ye. (2018). Analytical research of the stress-deformed state in the rock massif around faulting. International Journal of Engineering Research in Africa, (35), 77-88. https://doi.org/10.4028/www.scientific.net/jera.35.77

Majcherczyk, T., Niedbalski, Z., \& Malkowski, P. (2007). Measurements of roof support load in headings: In situ research. Technical, technological and economic aspects of thin-seams coal mining, International Mining Forum 2007, 37-46.

Naduty, V., Malanchuk, Z., Malanchuk, E., \& Korniyenko, V. (2015). Modeling of vibro screening at fine classification of metallic basalt. New Developments in Mining Engineering 2015: Theoretical and Practical Solutions of Mineral Resources Mining, 441-443. https://doi.org/10.1201/b19901-77

Rak, Z., Cieślik, J., Stasica, J., \& Dvořák, P. (2018). The importance of pre-tensioning cable bolts used to reinforce of arch yielding support. $A G 2018-4^{\text {th }}$ International Conference on Applied Geophysics. E3S Web of Conferences, (66), 03003. https://doi.org/10.1051/e3sconf/20186603003

Symanovych, G., Demydov, M., \& Chervatuk, V. (2013). Influence mechanism of rock mass structure forming a stress on a face support. Annual Scientific-Technical Collection - Mining of Mineral Deposits 2013, 77-81. https://doi.org/10.1201/b16354-15

Witek, M., \& Prusek, S. (2016) Numerical calculations of shield support stress based on laboratory test results. Computers and Geotechnics, (72), 74-88. https://doi.org/10.1016/i.compgeo.2015.11.007

Yu, H., Niu, Z., Kong, L., Hao, C., \& Cao, P. (2015). Mechanism and technology study of collaborative support with long and short bolts in large-deformation roadways. International Journal of Mining Science and Technology, 25(4), 587-593.

https://doi.org/10.1016/j.ijmst.2015.05.011

\section{ВПЛИВ ЖОРСТКОСТІ ОБВАЛЕНИХ ПОРІД ПОКРІВЛІ ВИРОБЛЕНОГО ПРОСТОРУ НА СТАН ПІДГОТОВЧИХ ВИРОБОК}

\section{В. Бондаренко, Г. Симанович, Є. Кіцкі, М. Барабаш, І. Салєєв}

Мета. Обгрунтування урахування деформаційно-силової характеристики обвалених і ущільнюючих порід виробленого простору поблизу підготовчої виробки, що повторно використовується, для оптимізації параметрів навантаження ії кріпильної й охоронної систем. Підвищення адекватності досліджень та достовірності рекомендацій.

Методика. Обчислювальними експериментами на основі методу скінченних елементів досліджувався вплив жорсткості обвалених і ущільнюючих порід виробленого простору на рівень напруженості вантажонесучих елементів кріпильної й охоронної систем виробки. Проведено аналіз напружено-деформованого стану вантажонесучих елементів геомеханічної системи та порівняльні шахтні дослідження. 
Результати. Наведено результати досліджень та аналіз напружено-деформованого стану елементів кріпильної й охоронної систем підготовчих виробок при різному ступені жорсткості обвалених і ущільнених порід виробленого простору. Оцінено закономірності впливу жорсткості обвалених порід покрівлі на стійкий стан підготовчих виробок.

Наукова новизна. Встановлено різновеликий зв'язок деформаційно-силових характеристик обвалених порід у виробленому просторі з елементами кріпильної й охоронної систем виробки, який необхідно враховувати при оптимізації режимів їх роботи. Виявлено, що підвищена завантаженість елементів комбінованої анкерної системи захищає рамне кріплення від підвищеного гірського тиску, що сприяє зниженню втрат перерізу виробки.

Практична значимість. Виконані дослідження є базою для оптимізації параметрів підтримання підготовчих виробок при їх повторному використанні, а також є основою для пошуку раціональних параметрів комбінованої анкерної системи з метою розробки методики вибору ії параметрів залежно від гірничо-геологічних умов.

Ключові слова: обвалені породи, підготовча виробка, напружено-деформований стан, деформаційно-силова характеристика, кріплення, жорсткість порід покрівлі

\title{
ВЛИЯНИЕ ЖЕСТКОСТИ ОБРУШЕННЫХ ПОРОД КРОВЛИ ВЫРАБОТАННОГО ПРОСТРАНСТВА НА СОСТОЯНИЕ ПОДГОТОВИТЕЛЬНЫХ ВЫРАБОТОК
}

\author{
В. Бондаренко, Г. Симанович, Е. Кицки, М. Барабаш, И. Салеев
}

Цель. Обоснование учета деформационно-силовой характеристики обрушенных и уплотняющихся вблизи повторно используемой подготовительной выработки пород выработанного пространства для оптимизации параметров нагружения ее крепежной и охранной систем. Повышение адекватности исследований и достоверности рекомендаций.

Методика. Вычислительными экспериментами на основе метода конечных элементов исследовалось влияние жесткости обрушенных и уплотняющихся пород выработанного пространства на уровень напряженности грузонесущих элементов крепежной и охранной систем выработки. Проведен анализ напряженно-деформированного состояния грузонесущих элементов геомеханической системы и сравнительные шахтные исследования.

Результаты. Приведены результаты исследований и анализ напряженно-деформированного состояния элементов крепежной и охранной систем подготовительных выработок при разной степени жесткости обрушенных и уплотненных пород выработанного пространства. Оценены закономерности влияния жесткости обрушенных пород кровли на устойчивое состояние подготовительных выработок.

Научная новизна. Установлена разновеликая связь деформационно-силовых характеристик обрушенных пород в выработанном пространстве с элементами крепежной и охранной систем выработки, что необходимо учитывать при оптимизации режимов их работы. Выявлено, что повышенная загруженность элементов комбинированной анкерной системы защищает рамную крепь от повышенного горного давления, что способствует снижению потерь сечения выработки.

Практическая значимость. Выполненные исследования являются базой для оптимизации параметров поддержания подготовительных выработок при их повторном использовании, а также являются основой для поиска рациональных параметров комбинированной анкерной системы с целью разработки методики выбора ее параметров в зависимости от горно-геологических условий.

Ключевые слова: обрушенные породы, подготовительная выработка, напряженно-деформированное состояние, деформационно-силовая характеристика, крепь, жесткость пород кровли

\section{ARTICLE INFO}

Received: 27 September 2018

Accepted: 28 March 2019

Available online: 8 April 2019

\section{ABOUT AUTHORS}

Volodymyr Bondarenko, Doctor of Technical Sciences, Head of the Underground Mining Department, Dnipro University of Technology, 19 Yavornytskoho Ave., 49005, Dnipro, Ukraine. E-mail: v domna@yahoo.com

Hennadii Symanovych, Doctor of Technical Sciences, Professor of the Department of Aerology and Labour Protection, Dnipro University of Technology, 19 Yavornytskoho Ave., 49005, Dnipro, Ukraine. E-mail: SymanovychG@nmu.org.ua

Jerzy Kicki, Doctor of Philosophy, Head of the Division of Mineral Resource Acquisition, Mineral and Energy Economy Research Institute of the Polish Academy of Sciences, 7 Wybickiego St, 31-261, Krakow, Poland. E-mail: jkicki@min-pan.krakow.pl

Mykhailo Barabash, Director for Production of the LLC “DTEK Energy”, 57 Lva Tolstoho St, 01032, Kyiv, Ukraine. E-mail: BarabashMV@dtek.com

Ildar Salieiev, CEO - Chairmen of Board PJSC "Donetsksteel” - Iron and Steel Works", 30 Lesi Ukrainky Blvd, 01133, Kyiv, Ukraine. E-mail: i.a.saleev@,donetsksteel.com 